\title{
Forecasting of Groundwater Salinity Changes and Yield of Some Crops by Integration of Time Series Analysis and GIS at Wadi El-Natrun Area, Egypt
}

\author{
Aggag, A .M
}

\begin{abstract}
Wadi El-Natrun region has recently undergone extensive urban and agricultural expansion. The main water resource for irrigation in this region is the groundwater aquifer. Extensive use of the aquifer water could cause a shortage in water storage and secondary salinization for this water, and a crop yield reduction. So, the objective of this study is to set efficient strategy to ensure long-term sustainability of the region's agricultural production.
\end{abstract}

The electrical conductivity (EC) database of the baseline period (1966-2014), for twenty-seven wells of Wadi El-Natrun, were used to apply the time series statistical analysis to forecast EC data of the future period (2015-2050). Multitemporal forecasted EC data was used to classify the groundwater, detect the annual and periodical changes of groundwater salinity, and determine the periodical and annual water potential risk to salinity hazards. The results of the forecasted EC data indicated that the category of very salty groundwater dominated in the northern sector, while the moderately salty and salty groundwater categories dominated in the southern sector. The annual changes of groundwater salinity increased through the period of $2015-2050$. The increase ranged from $0.95 \%$ to $1.35 \%$ with annual mean of $1.13 \%$ for the southern and northern sectors.

The forecasted EC and an innovative and interpretative scale were conducted to estimate the periodical (PPRSH) and annual (APRSH) water potential risk to salinity hazard of the future period (2015-2050). The results indicated that the classes of no risk and moderately potential risk were dominant in the southern and northern sectors. Regarding the crop yield, in 1966, about $68.80 \%$ of the area under investigation produced $100 \%$ of citrus yield and $30.62 \%$ of area produced from 75 to $99 \%$ of the yield, while $89.9 \%$ of area produces $100 \%$ of tomato yield and $10.1 \%$ of area produce between 75 to $\mathbf{9 9 \%}$ of yield. Based on the forecasted groundwater salinity in 2050 , the area of $100 \%$ of citrus production will be reduced to $1.41 \%$ and $52.64 \%$ of the area will produce less than $75 \%$. At the same time, $16.44 \%$ of the area become out of citrus production. The area of $100 \%$ of tomato production will be reduced to $27.3 \%$ and $38.15 \%$ of the area will produce less than $\mathbf{5 0 \%}$.

Keywords: Forecast, Groundwater, Salinity, time series analysis, water potential risk to salinity hazard.

\section{INTRODUCTION}

Demand for the world's water supply is raising rapidly that sets the food production in the world at risk.
Agricultural production, industrial, household, and environmental uses contribute for scarce water supply sources. As demands for water by all users grows, groundwater sources are being depleted; other water sources are becoming polluted and degraded (Masoud and Atwia, 2011 and Masoud, 2014). Additionally, quality of groundwater is degraded rapidly with the increasing massive industrialization, urbanization, and agricultural expansion with its associated activities. Degradation of the groundwater quality is commonly linked to its chemistry variables (Dawoud, 2004 and Kim et al., 2005).

Steady increase of Egypt's population must be faced by enhanced sustainable of management of newly reclaimed soils, such as Wadi El-Natrun region. The groundwater in this region is considered as a unique water resource for the irrigation purposes (Youssef et al., 2012). During the recent years, increasing obstacles to meet the increasing the demands for domestic supplies and expansion in desert reclaimed soils has raised concerns for the sustainability of the groundwater resource (El Arabi, 2012).

The impacts of climate change on both the supply and demand of water resources management are also becoming increasingly important globally (Green et al. 2011). For the area of Wadi El-Natrun, reference evapotranspiration is projected to increase by more than $9 \%$ by year of 2025 (Candela et al., 2012), while changes in precipitation are projected to be nil (Terink et al. 2013).

The high groundwater use and land management practices in the agricultural area of Wadi El-Natrun have resulted in the degradation of groundwater quality and quantity. Primary concerns among users are salinization from declining water levels (King and Salem, 2012; Ibrahim, 2005; and Fattah, 2011). These problems have raised questions about the sustainability and potential risks of the current water use regime on local water, food and economic security in the area, particularly as climate change is projected to add additional pressures to water demand (Switzman, 2013).

Time-series analysis is becoming an increasingly important method of studying temporal variations in groundwater quality and hydrology. It is used for building mathematical models to generate synthetic

\footnotetext{
Nat. Res. \& Agric. Eng. Dept., Fac. Agric., Damanhour Univ., Egypt

Corresponding author: aggag5@dmu.edu.eg

Received February 15, 2016, Accepted March 13, 2016
} 
hydrologic records, to forecast hydrologic events, to detect trends and shifts in hydrologic records. Kim et al. (2005) applied time-series analysis to study the temporal variations effects of tidal pressure on groundwater quality in particular the salinity level, and how they vary over time.

Change detection is the process of identifying differences in the state of an object or phenomenon by observing it at different times. Essentially, it involves the ability to quantify temporal effects using multitemporal data. Thus, change detection has become a major application of geographic information system (GIS) data because of repetitive coverage at short intervals and consistent image quality (Abd El-Hady et al. 2014 and 2015).

Accordingly, an agricultural strategy for Wadi ElNatrun region is needed for the period 2015-2050. The strategy requires future data about the groundwater quality and the crops growing in this region. Therefore, the present study aims to: (1) monitor future changes of groundwater salinity using time series analysis, (2) forecast the yield, of some crops such as tomato and citrus as function of groundwater salinity, and (3) evaluate and map the groundwater suitability for citrus and tomato productions.

\section{MATERIALS AND METHODS}

\section{Studied Area}

Wadi El-Natrun is a narrow depression located in the west of Nile Delta, approximately $110 \mathrm{~km}$ northwest
Cairo, between longitudes $30^{\circ} 02^{\prime}$ and $30^{\circ} 29^{\prime} \mathrm{E}$ and latitudes $30^{\circ} 16^{\prime}$ and $30^{\circ} 32^{\prime} \mathrm{N}$ (Fig. 1). The total area of Wadi El-Natrun region is about $281.7 \mathrm{Km}^{2}$ (i.e. 28406 Hectares). The region is located in a NW-SE direction and has an average elevation of $23 \mathrm{~m}$ below sea level. This region has considerable potential for agricultural production due to its location and to the availability of groundwater for irrigation. The origin of the underground water in Wadi El-Natrun is lateral seepage from the Nile Delta and from Moghara aquifer, due to its proximity and low level (El-Maghraby, 1990). It is also recharges from the south by Nile Delta water through Wadi El Farigh (Abdel Baki, 1983 and Sharaky et al., 2007). Wadi El-Natrun area is extremely arid region where the mean annual rainfall, evaporation and temperature are $41.4 \mathrm{~mm}, 114.3 \mathrm{~mm}$ and $21^{\circ} \mathrm{C}$, respectively (Egyptian Metrological Authority, 2006).

\section{Quality of Groundwater}

Salinity data of groundwater samples of twenty seven wells were collected by Wadi El-Natrun Authority and Desert Development Center (Sabbah and Metwally, 1997) to represent the groundwater wells of the northern and southern sectors of Wadi El-Natrun. The EC data period (1996-2014) is consisted as a past base line to enable for forecasting EC for the future period (2015-2050). The groundwaters of the studied wells were classified, based on the forecasted EC, according to the system of Government of Western Australia, Department of Agriculture (2015), and are shown in Table (1).

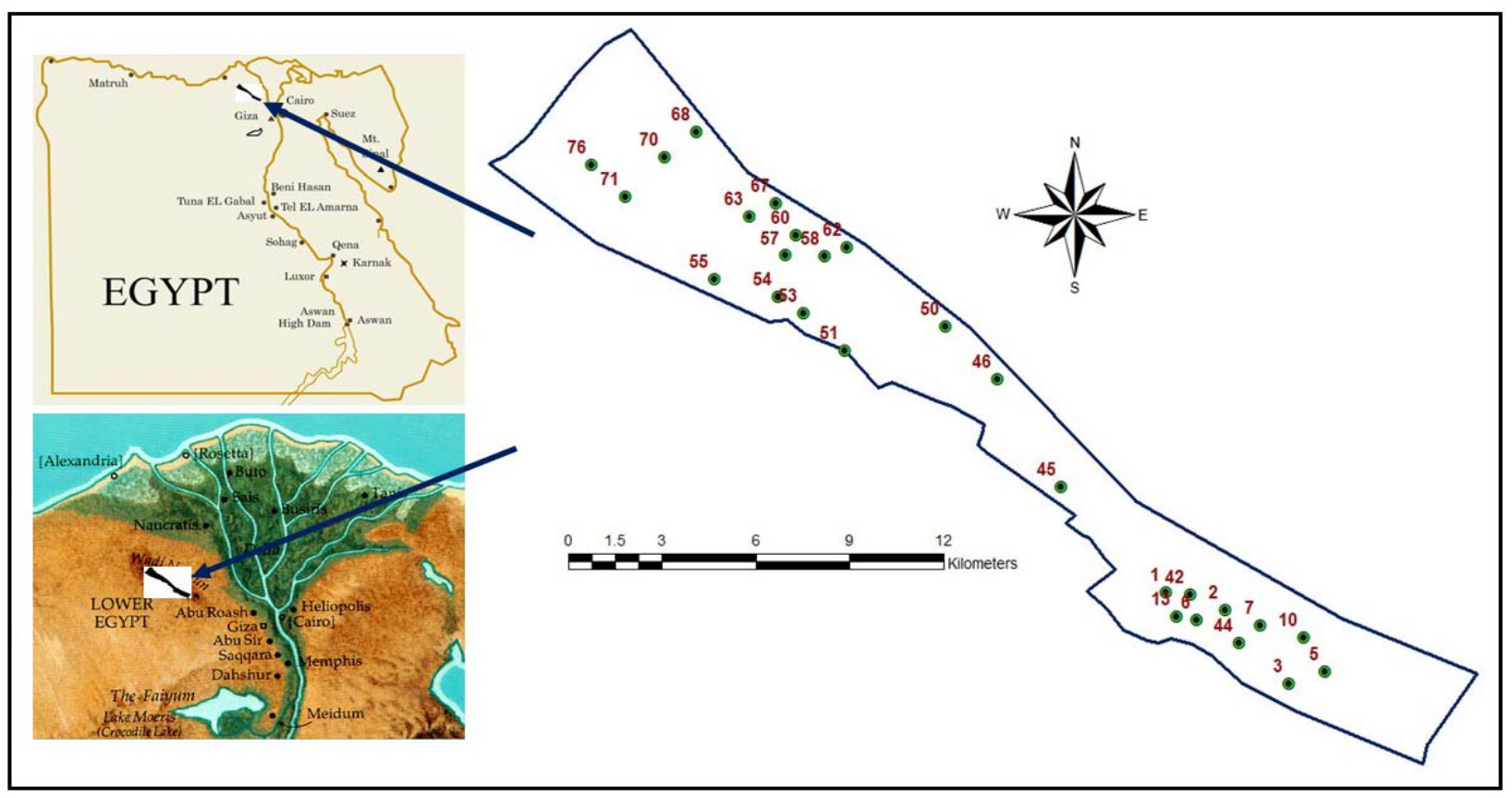

Fig1. Location of studied area and wells 
Table 1. Water salinity classification

\begin{tabular}{lccc}
\hline $\mathbf{E C}\left(\mathbf{d S m}^{-1}\right)$ & Salinity Class & $\mathbf{E C ~}\left(\mathbf{d S m}^{-1}\right)$ & Salinity Class \\
\hline $0.0-0.80$ & Low salinity & $2.50-5.00$ & Salty \\
\hline $0.08-2.50$ & Moderately salty & $>5$ & Very Salty \\
\hline
\end{tabular}

\section{Forecasting Groundwater Status}

(a) Forecasting EC Data of 2015-2050: The collected annual EC data of the groundwater of the baseline past period (1966-2014) wasutilized to compose the salinity and to forecast the groundwater salinity of the future period of 2015-2050. This forecasting was elaborated by using the statistical time series analysis named Zaitun Software Version 2.1 (Fathony et al., 2009). This Version included the following steps:

-Composition of the type of time series by selecting EC data measured, at the same time, (January of each year of the base past period: 1966-2014, to minimize data seasonality of flow time series.

- Determination of decomposition model type: The two types of model of time series decomposition are the additive decomposition model and the multiplicative model. Reliable type of the decomposition model is determined according to Trend Line (Lee and Lee, 2000; Tularam and Keeler, 2006; and wikipedia, 2015) which was the additive decomposition model.

- Determination of the fitting trend equation.

(b) Calculation of EC descriptive statistics: The descriptive statistics of the EC data of past baseline period (1966-2014) and the future period (20152050) were used to study periodical changes of groundwater salinity.

(c) Assessment of annual and periodical future potential risk of salinity hazards:

The indictors of periodical (PPRSH) and annual (APRSH) water potential risk with respect to salinity hazard, of the future period (2015-2050), were expressed as follows:

$$
\left.\operatorname{PPRSH}(\mathrm{y} 1-\mathrm{yt}) \%=\sum_{y=t}^{y=1} 100 * E C y 1-E C y t\right) / E C y t
$$

where:

PPRSH $(\%)=$ Periodical Potential Risk to Salinity Hazard for a period from year $=1$ to year $=\mathrm{t}$. The mean of $(\mathrm{PPRSH})$, i.e $=(\mathrm{PPRSH}) /(\mathrm{Y} 1-\mathrm{Yt})$,

APRSH $(\%)=$ Annual Potential Risk to Salinity Hazard and the interpretative scale was established to classify the studied groundwater,

ECy1 = the electrical conductivity at year 1, and

$\mathrm{ECyt}=$ the electrical conductivity at year $\mathrm{t}$.

\section{GIS Mapping of Crops Yield:}

Forecasted EC data of the future period (2015-2050) were used to estimate the yield of citrus and tomato, the most common cultivated crops in the area, using Ayers and Westcot (1985). The estimated yields of citrus and tomato were incorporated with the coordinates of the groundwater wells to map the forecasted yield of citrus and tomato for the years of 1966, 2015 and 2050, using ArcMap10 GIS Package (ESRI 2010).

\section{RESULTS AND DISCUSSIONS}

\section{1) Establishment Future EC database}

\section{- Determination of the type and composition model of EC time series:}

Simply, there are two types of data time series flow and stock series. The concept of stock series was applied to compose EC data time series by selecting EC data measured at the same time (January of each year) of the baseline period (1966-2014). This time series type enabled to avoid partially the data seasonality of flow time series that conduct to unreliable forecasting. Hence, stock time series of baseline EC data could not completely remove all seasonal variation. So, it was necessary to determine type of decomposition model that is capable to remove the remaining seasonal variation.

The two types of time series decomposition models, additive and multiplicative, were formulated to investigate the behavior of the trend line of EC data (Fig. 2). The trend analysis of EC data of the baseline period (1966-2014) showed that the fluctuations effects are independent of the trend behavior; the amplitude of irregular variations does not change as the level of the trend rises or falls. In addition, cyclic effects behaved in constant manner from year to year. For these reasons, the additive model was selected to decompose this series type.

\section{- Equations describing the trend of EC data in the baseline period:}

The different types of equations describing the trend of EC data were defined to dictate the more reliable trend equation that had the minimal mean squared error (MSE). As an example, four equations expressing the trend of EC data of well No.1 are shown in Table (2). In addition, the MSE is shown. The most reliable equation is the exponential one because it has the minimal (MSE) as shown in Table 2. Similarly, all other EC data of the other wells were expressed using the exponential equation. 


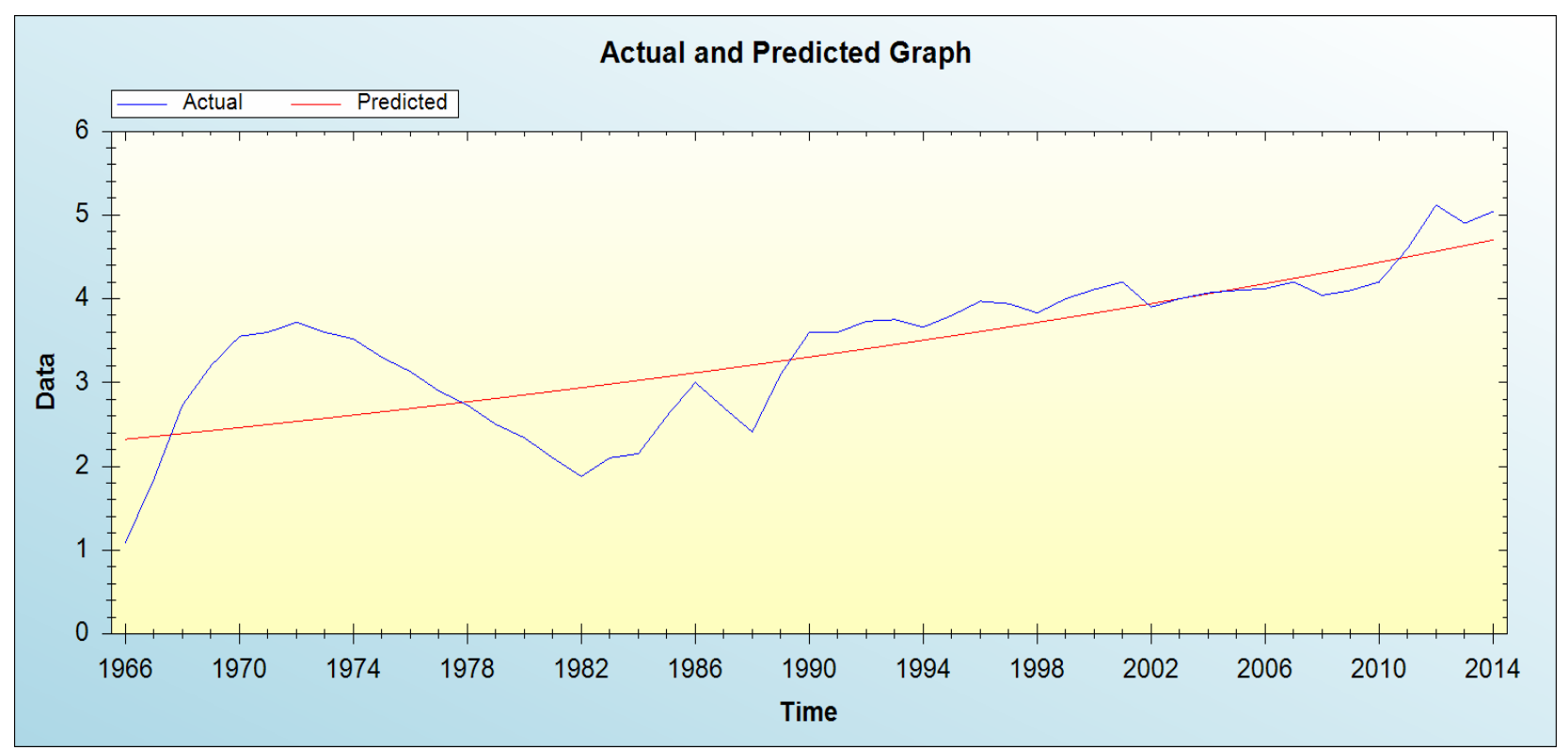

Fig 2. Trend of EC time series (1966-2014) of well No.1

Table 2. Trend equations of groundwater EC data (1966-2014) of well No.1

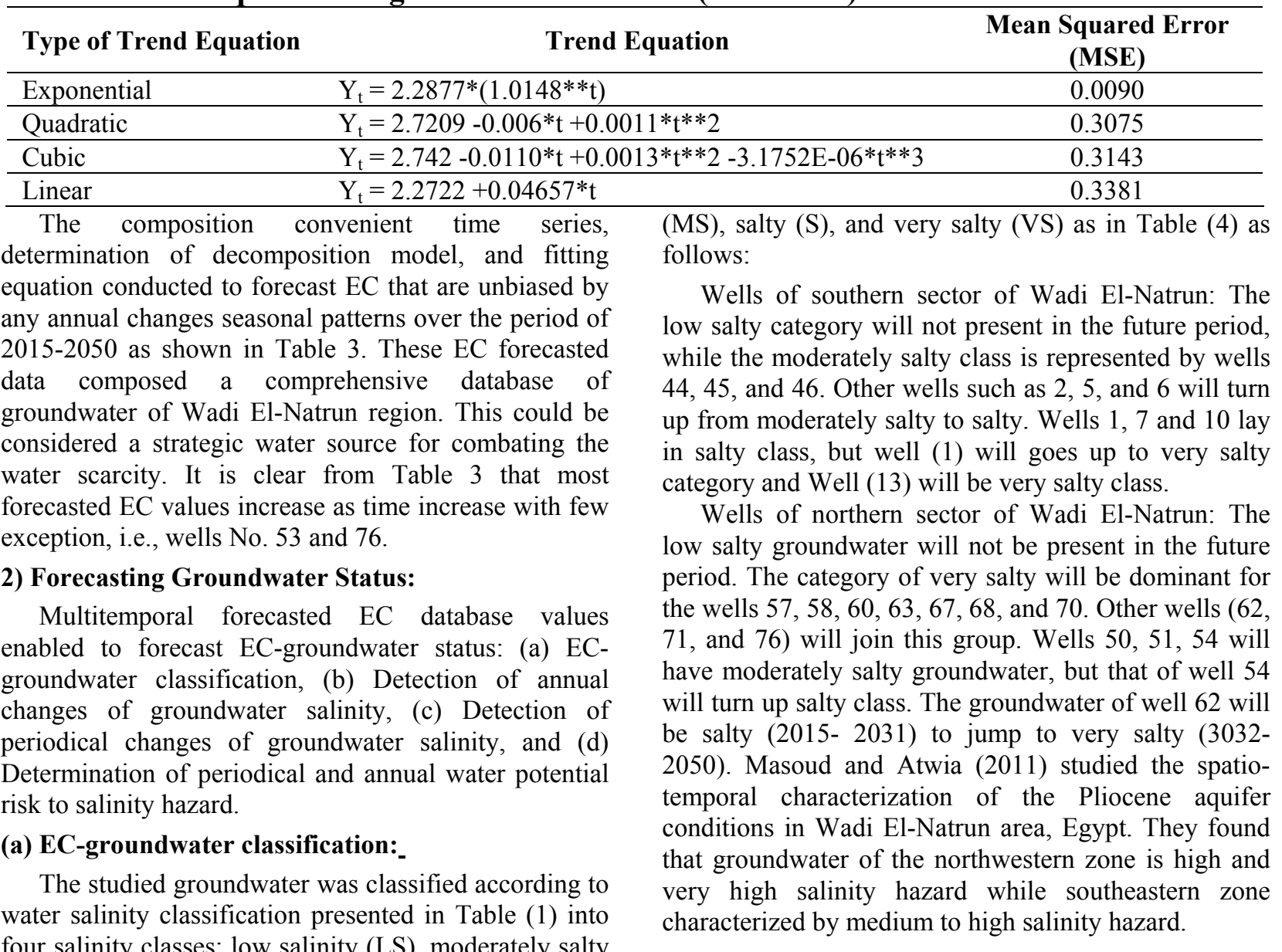
four salinity classes: low salinity (LS), moderately salty 


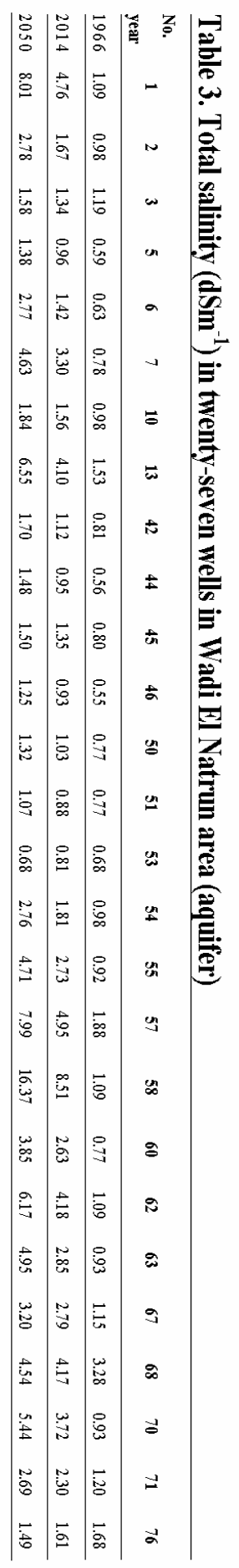




\section{(b) Detection of Annual Changes of Groundwater Salinity:}

Multitemporal forecasted EC (Table 3) was used to monitor the annual changes of groundwater salinity, of each well, over the years of the future period (20152050). The EC values tended to increase annually, with exception of wells $(53,76)$. This comprehensive EC data enabled to calculate the annual rate of increasing salinity that have positive values for all wells. Masoud and Atwia (2011) Studied the spatio-temporal characterizations of Wadi El-Natrun groundwater in 2006 and 2007. They found that the northwestern zone showed high to very high salinity hazard while the southeastern zone samples showed medium to high salinity hazard. Two wells $(53,76)$ had negative values $(-0.34$, and $-0.09 \%$, respectively). This negative sign indicated salinity decreasing tendency. These decreases may be due to lower discharge and minimum operating time in latest few years for these two wells compared to other wells.

Also, data of EC indicated that the maximal annual increasing salinity ( $2 \%$ ) that was recorded (well 6) will occur through the period (2015-2018). In addition, the EC of the groundwater of well 68 will have the minimal salinity with of increasing rate $0.26 \%$ along the years from 2015 to 2050 . The water of wells of southern and northern sectors of Wadi El-Natrun had averaged annual salinity increasing of $3.36 \%$ and $4.48 \%$, respectively. In addition, the results showed that the annual general mean (all studied wells) salinity increasing had the value of $36.78 \%$. According to the EC values, the studied wells can be arranged in ascending series as follows:

- The wells of southern sector of Wadi El-Natrun; 5, 46, 44, 42, 6, 3, 45, 2, 10, 7, 13 and 1 .

- The wells of northern sector of Wadi El-Natrun; 53, $51,50,76,54,55,71,60,63,67,70,62,68,57$ and 58.

(c) Detection of Periodical Changes of Groundwater Salinity:

The descriptive analysis of the forecasted EC means of the future period (2015-2050) were calculated to determine the mean, minimum and maximum EC data (Table 3). The means indicated that the studied wells can be classified into four groups according to their periodic salinity: (a) low salty (well No. 53 with EC of 0.74); (b) moderately salty (wells No. 2, 3, 5, 6, 10, 42, $44,45,46,50,51,54,71$, and 76 with EC range 1.08 to 2.49); (c) salty (wells No. 7, 55, 60, 63, 67, and 70 with EC range 3.20 to 4.53 ); and (d) very salty (wells No. 1 , $13,57,58,62$ with EC range 5.23 to12.03). At regional and periodical scales, wells of Wadi El-Natrun may have averaged, minimum and maximum EC values of 3.80, 0.68 and $16.37 \mathrm{dSm}^{-1}$, respectively (Table 4) during the future period. According to Abdel-Baki (1983); Wadi El-Natrun area has two water bearing horizons that separated by a thick clay layer.

The upper water horizon has high saline water while the lower water horizon has low saline water. The separated layer changes laterally to the south and east into sandy layer allowing interaction of water in the two layers.

Descriptive statistics of groundwater salinity of the baseline period (1966- 2014) were calculated from collected data and illustrated in Tables (5 and 6). The mean, minimum and maximum EC values were 1.79, 0.54 and $6.68 \mathrm{dSm}^{-1}$, respectively. The comparison of descriptive statistics of EC groundwater, of the past and future periods, indicated that the regional averaged salinity increased from 1.79 to $3.87 \mathrm{dSm}^{-1}$. The maximum regional EC value, increased from $6.68 \mathrm{dSm}^{-}$ ${ }^{1}$ (in the past baseline period: $1966-2014$ ) to $16.37 \mathrm{dSm}^{-}$ ${ }^{1}$ (in the future period: 2015-2050).

\section{(d) Determination of periodical and annual water potential risk to salinity hazard:}

Salinity annual increasing rate was considered as a parameter to assess risk potentiality to salinity hazard. This rate was conducted to calculate the indices of periodical (PPRSH) and annual (APRSH) water potential risk to salinity hazard for the future period (2015-2050). Hence, groundwater must be classified, by potentiality to salinity hazard; it was required to establish an innovative and interpretative scale. This scale is based on calculation of the predicated EC and the groundwater salinity classification. The innovative and interpretative scale had the advantage of compiling water salinity classes and EC annual increasing percentage. It consists of five categories of risk potentiality to salinity hazard: no risk, moderately potential risk, high potential risk, very high potential risk and out of agricultural uses (Table 7).

The studied groundwater was classified to monitor the predicated change of the future period (2015-2050). The scale indicated that the classes of no risk and moderately potential risk were dominant in Wadi ElNatrun (Table 8). Table (8) also indicated that in southern sector, about $75 \%$ of wells have no salinity potential risk, while $17 \%$ of wells have moderately salinity potential risk and well No.1 has high potential risk. On the other hand, in norther sector, about $40 \%$ of wells has no potential risk also, $40 \%$ of wells has moderately potential risk, while well No.62 has high potential risk and well No.58 is out of agriculture use. The advantage of the annual and periodical future 
potential risk of salinity hazard guides the agricultural decision makers to plan of crops cultivation at short and long runs.

\section{3) Yield Prediction as a function of Water Salinity Changes:}

\section{Citrus:}

Table (9) and figure (3) showed area cultivated with citrus. A $68.80 \%$ of the area produces $100 \%$ of citrus yield while $30.62 \%$ of the area produces from 75 to $99 \%$ of citrus in 1966 . In 2015 , the corresponding areas were $17.56 \%$ and $25.71 \%$. In $2050,1.41 \%$ of the area will produce $100 \%$ of the citrus yield while 29.5 of the area will produce 75 to $99 \%$ of yield. It is expected that in $2050,16.44 \%$ of the area become out of citrus production.

\section{Tomato:}

Table (10) and figure (4) showed area cultivated with tomato and its production. In the year 1966, $89.90 \%$ of the area produced $100 \%$ of tomato yield while $10.10 \%$ of the area produced from 75 to $99 \%$ of tomato yield. In 2015 , the area of $100 \%$ of production was reduced to $32.20 \%$ of the area and production of 75 to $99 \%$ of production was increased to $50.80 \%$ of the area. In 2050, according to forecasted groundwater salinity, the area of $100 \%$ of production will be reduced to $27.30 \%$, and $52.90 \%$ of the area produces between 50 to $75 \%$. At the same time, $19.00 \%$ of the area produces less than $50 \%$ of tomato yield.

Table 4. EC-groundwater classification of Wadi El-Natrun

\begin{tabular}{|c|c|c|c|c|c|}
\hline \multicolumn{6}{|c|}{ Wells of southern sector of Wadi El-Natrun } \\
\hline $\begin{array}{l}\text { Well } \\
\text { No. }\end{array}$ & $\begin{array}{c}\text { EC-Forecasted Changes } \\
\left(E C_{\min }\right) \text { to }\left(E C_{\max }\right)\end{array}$ & $\begin{array}{l}\text { Salinity } \\
\text { Class }\end{array}$ & $\begin{array}{l}\text { Well } \\
\text { No. }\end{array}$ & $\begin{array}{c}\text { EC -Forecasted Changes } \\
\left(E C_{\min }\right) \text { to }\left(E C_{\max }\right)\end{array}$ & $\begin{array}{c}\text { Salinity } \\
\text { Class }\end{array}$ \\
\hline \multirow{2}{*}{1} & $2015(4.76)-2018(5.00)$ & $\mathrm{S}$ & 7 & $2015(3.3)-2050(4.63)$ & $\mathrm{S}$ \\
\hline & $2019(5.04)-2050(8.01)$ & VS & 10 & $2015(1.56)-2050(1.84)$ & $\mathrm{S}$ \\
\hline \multirow{2}{*}{2} & $2015(1.67)-2042(2.47)$ & MS & \multirow{2}{*}{13} & $2015(4.10)-2029(4.93)$ & $\mathrm{S}$ \\
\hline & $2043(2.53)-2050(2.78)$ & $\mathrm{S}$ & & $2030(5.03)-2050(6.55)$ & VS \\
\hline 3 & $2015(1.34)-2050(1.58)$ & MS & 42 & $2015(1.12)-2050(1.7)$ & $\mathrm{S}$ \\
\hline 5 & $2015(0.96)-2050(1.38)$ & MS & 44 & $2015(0.95)-2050(1.48)$ & MS \\
\hline \multirow{2}{*}{6} & $2015(1.42)-2044(2.43)$ & MS & 45 & $2015(1.35)-2050(1.50)$ & MS \\
\hline & $2045(2.52)-2050(2.77)$ & $\mathrm{S}$ & 46 & $2015(0.93)-2050(1.25)$ & MS \\
\hline \multicolumn{6}{|c|}{ Wells of northern sector of Wadi El-Natrun } \\
\hline $\begin{array}{l}\text { Well } \\
\text { No. }\end{array}$ & $\begin{array}{c}\text { EC -Forecasted Changes } \\
\left(E C_{\min }\right) \text { to }\left(E C_{\max }\right)\end{array}$ & $\begin{array}{l}\text { Salinity } \\
\text { Class }\end{array}$ & $\begin{array}{l}\text { Well } \\
\text { No. }\end{array}$ & $\begin{array}{c}\text { EC-Forecasted Changes } \\
\left(E C_{\min }\right) \text { to }\left(\mathrm{EC}_{\max }\right)\end{array}$ & $\begin{array}{c}\text { Salinity } \\
\text { Class }\end{array}$ \\
\hline 50 & $2015(1.03)-2050(1.32)$ & MS & \multirow{2}{*}{62} & $2015(4.18)-2031(4.99)$ & $\mathrm{S}$ \\
\hline 51 & $2015(0.88)-2050(1.07)$ & MS & & $2032(5.06) 2050(6.17)$ & VS \\
\hline 53 & $2015(0.80)-2050(0.68)$ & LS & 63 & $2015(2.85)-2050(4.95)$ & $\mathrm{S}$ \\
\hline \multirow{2}{*}{54} & $2015(1.81)-2041(2.47)$ & MS & 67 & 2015 (2.79)-2050 (3.2) & $\mathrm{S}$ \\
\hline & $2042(2.51)-2050(2.76)$ & $\mathrm{S}$ & 68 & $2015(4.17)-2050(4.54)$ & $\mathrm{S}$ \\
\hline 55 & $2015(2.73)-2050(4.71)$ & $\mathrm{S}$ & 70 & $2015(3.72)-2042(4.99)$ & $\mathrm{S}$ \\
\hline 57 & $2015(5.02)-2050(7.99)$ & VS & \multirow{2}{*}{71} & 2015 (2.30)- 2034 (2.5) & MS \\
\hline 58 & $2015(8.51)-2050(16.37)$ & VS & & $2034(5.03)-2050(5.44)$ & VS \\
\hline 60 & $2015(2.63)-2050(3.85)$ & $\mathrm{S}$ & 76 & $2015(1.49)-2050(1.62)$ & MS \\
\hline
\end{tabular}

Table 5-a. Descriptive statistics of groundwater forecasted salinity of the future period (2015-2050) of the southern sector of Wadi El-Natrun

\begin{tabular}{|c|c|c|c|c|c|c|c|c|c|c|c|}
\hline \multirow{2}{*}{$\begin{array}{l}\text { Well } \\
\text { No. }\end{array}$} & \multicolumn{3}{|c|}{$\begin{array}{c}\text { Descriptive Statistical } \\
\text { Parameters }\end{array}$} & \multirow{2}{*}{$\begin{array}{l}\text { Well } \\
\text { No. }\end{array}$} & & & & \multirow{2}{*}{$\begin{array}{l}\text { Well } \\
\text { No. }\end{array}$} & \multirow[b]{2}{*}{ Mean } & \multirow[b]{2}{*}{ Min. } & \multirow[b]{2}{*}{ Max. } \\
\hline & Mean & Min. & Max. & & Mean & Min. & Max. & & & & \\
\hline 1 & 6.24 & 4.76 & 8.01 & 6 & 2.02 & 1.42 & 2.77 & 42 & 1.39 & 1.12 & 1.70 \\
\hline 2 & 2.18 & 1.67 & 2.78 & 7 & 3.93 & 3.30 & 4.63 & 44 & 1.20 & 0.95 & 1.48 \\
\hline 3 & 1.46 & 1.34 & 1.58 & 10 & 1.70 & 1.56 & 1.84 & 45 & 1.42 & 1.35 & 1.50 \\
\hline 5 & 1.16 & 0.96 & 1.38 & 13 & 5.23 & 4.10 & 6.55 & 46 & 1.08 & 0.93 & 1.25 \\
\hline
\end{tabular}


Table 5-b. Descriptive statistics of groundwater forecasted salinity of the future period (2015-2050) of the northern sector of Wadi El-Natrun

\begin{tabular}{|c|c|c|c|c|c|c|c|c|c|c|c|}
\hline \multirow{2}{*}{$\begin{array}{l}\text { Well } \\
\text { No. }\end{array}$} & \multicolumn{3}{|c|}{$\begin{array}{c}\text { Descriptive Statistical } \\
\text { Parameters }\end{array}$} & \multirow{2}{*}{$\begin{array}{l}\text { Well } \\
\text { No. }\end{array}$} & \multicolumn{3}{|c|}{$\begin{array}{c}\text { Descriptive Statistical } \\
\text { Parameters }\end{array}$} & \multirow{2}{*}{$\begin{array}{l}\text { Well } \\
\text { No. }\end{array}$} & \multicolumn{3}{|c|}{$\begin{array}{c}\text { Descriptive Statistical } \\
\text { Parameters }\end{array}$} \\
\hline & Mean & Min. & Max. & & Mean & Min. & Max. & & Mean & Min. & Max. \\
\hline 50 & 1.17 & 1.03 & 1.32 & 57 & 6.36 & 5.01 & 7.99 & 67 & 2.99 & 2.79 & 3.20 \\
\hline 51 & 0.97 & 0.88 & 1.07 & 58 & 12.03 & 8.51 & 16.37 & 68 & 4.35 & 4.17 & 4.54 \\
\hline 53 & 0.74 & 0.68 & 0.80 & 60 & 3.20 & 2.63 & 3.85 & 70 & 4.53 & 3.72 & 5.44 \\
\hline 54 & 2.25 & 1.81 & 2.76 & 62 & 5.11 & 4.18 & 6.17 & 71 & 2.49 & 2.30 & 2.69 \\
\hline 55 & 3.63 & 2.73 & 4.71 & 63 & 3.81 & 2.85 & 4.95 & 76 & 1.55 & 1.49 & 1.62 \\
\hline
\end{tabular}

Table 6-a. Descriptive statistics of groundwater salinity (EC) of the past base period (1966 2014) of the southern sector of Wadi El-Natrun

\begin{tabular}{|c|c|c|c|c|c|c|c|c|c|c|c|}
\hline \multirow[t]{2}{*}{$\begin{array}{l}\text { Well } \\
\text { No. }\end{array}$} & \multicolumn{3}{|c|}{$\begin{array}{l}\text { Descriptive Statistical } \\
\text { Parameters } \\
\left(\mathbf{E C}, \mathbf{d S m}^{-1}\right)\end{array}$} & \multirow[t]{2}{*}{$\begin{array}{l}\text { Well } \\
\text { No. }\end{array}$} & \multicolumn{3}{|c|}{$\begin{array}{c}\text { Descriptive Statistical } \\
\text { Parameters } \\
\left(\mathrm{EC}, \mathrm{dSm}^{-1}\right)\end{array}$} & \multirow[t]{2}{*}{$\begin{array}{l}\text { Well } \\
\text { No. }\end{array}$} & \multicolumn{3}{|c|}{$\begin{array}{c}\text { Descriptive Statistical } \\
\text { Parameters } \\
\left(\mathbf{E C}, \mathbf{d S m}^{-1}\right)\end{array}$} \\
\hline & Mean & Min. & Max. & & Mean & Min. & Max. & & Mean & Min. & Max. \\
\hline 1 & 3.44 & 1.09 & 5.12 & 6 & 0.91 & 0.44 & 1.22 & 42 & 0.85 & 0.48 & 1.08 \\
\hline 2 & 1.18 & 0.71 & 1.68 & 7 & 2.62 & 1.44 & 3.11 & 44 & 0.71 & 0.46 & 0.96 \\
\hline 3 & 1.20 & 0.86 & 1.45 & 10 & 1.39 & 1.08 & 1.79 & 45 & 1.27 & 0.80 & 1.64 \\
\hline 5 & 0.76 & 0.49 & 0.91 & 13 & 3.02 & 1.4 & 3.58 & 46 & 0.76 & 0.50 & 1.00 \\
\hline
\end{tabular}

Table 6-b. Descriptive statistics of groundwater forecasted salinity of the past base period $(1966$ - 2014) of the northern sector of Wadi El-Natrun

\begin{tabular}{|c|c|c|c|c|c|c|c|c|c|c|c|}
\hline \multirow{2}{*}{$\begin{array}{l}\text { Well } \\
\text { No. }\end{array}$} & \multicolumn{3}{|c|}{$\begin{array}{l}\text { Descriptive Statistical } \\
\text { Parameters (EC,dSm-1) }\end{array}$} & \multirow{2}{*}{$\begin{array}{l}\text { Well } \\
\text { No. }\end{array}$} & \multicolumn{3}{|c|}{$\begin{array}{c}\text { Descriptive Statistical } \\
\text { Parameters (EC,dSm-1) }\end{array}$} & \multirow{2}{*}{$\begin{array}{l}\text { Well } \\
\text { No. }\end{array}$} & \multicolumn{3}{|c|}{$\begin{array}{l}\text { Descriptive Statistical } \\
\text { Parameters (EC,dSm-1) }\end{array}$} \\
\hline & Mean & Min. & Max. & & Mean & Min. & Max. & & Mean & Min. & Max. \\
\hline 50 & 0.87 & 0.67 & 1.12 & 57 & 3.60 & 1.88 & 4.45 & 67 & 2.52 & 1.84 & 2.81 \\
\hline 51 & 0.78 & 0.60 & 0.95 & 58 & 5.64 & 1.09 & 7.27 & 68 & 3.95 & 3.20 & 4.47 \\
\hline 53 & 0.91 & 0.68 & 1.48 & 60 & 2.05 & 0.97 & 2.47 & 70 & 2.89 & 1.68 & 3.57 \\
\hline 54 & 1.37 & 0.71 & 1.75 & 62 & 3.24 & 1.09 & 3.88 & 71 & 2.06 & 1.44 & 2.45 \\
\hline 55 & 1.90 & 0.88 & 2.33 & 63 & 1.97 & 0.93 & 2.48 & 76 & 1.72 & 1.48 & 2.09 \\
\hline
\end{tabular}

Table 7. Interpretative scale of the annual and periodical potential risk of salinity hazard (APRSH, \%)

\begin{tabular}{|c|c|c|c|c|c|c|}
\hline \multirow{2}{*}{$\begin{array}{l}\text { Salinity } \\
\text { Class }\end{array}$} & \multirow{2}{*}{$\begin{array}{c}\text { Annual } \\
\text { increasing } \\
(\%)\end{array}$} & \multicolumn{2}{|c|}{$\begin{array}{c}\text { Predicated Increasing of } \\
E C\left(\mathbf{d S m}^{-1}\right)\end{array}$} & \multicolumn{2}{|c|}{$\begin{array}{l}\text { Predicated } \\
\text { EC }\left(\mathrm{dSm}^{-1}\right)\end{array}$} & \multirow{2}{*}{$\begin{array}{c}\text { Class of Salinity Potentia } \\
\text { Risk }\end{array}$} \\
\hline & & 1 year & 20 years & 1 year & 20 years & \\
\hline \multirow{4}{*}{$0.0-0.8$} & 25 & 0.2 & 4 & 1 & 4.8 & No Risk \\
\hline & 50 & 0.4 & 8 & 1.2 & 8.8 & Moderately Potential Risk \\
\hline & 75 & 0.6 & 12 & 1.4 & 12.8 & High Potential Risk \\
\hline & $>75$ & $>0.6$ & $>12$ & $>1.4$ & $>12.8$ & Very High Potential Risk \\
\hline \multirow{4}{*}{$>0.8-2.5$} & $\leq 5$ & 0.13 & 2.6 & 7.63 & 5.1 & No Risk \\
\hline & $>5-\leq 10$ & 0.25 & 5 & 7.75 & 12.5 & Moderately Potential Risk \\
\hline & $>10-\leq 15$ & 0.38 & 7.6 & 7.88 & 15.1 & High Potential Risk \\
\hline & $>15$ & $>0.38$ & $>7.6$ & $>7.88$ & $>15.1$ & Very High Potential Risk \\
\hline \multirow{3}{*}{$>2.5-5.0$} & $\leq 2.5$ & 0.13 & 2.6 & 5.13 & 7.6 & Moderately Potential Risk \\
\hline & $>2.5-\leq 5$ & 0.25 & 5 & 5.25 & 10 & High Potential Risk \\
\hline & $>5$ & 0.50 & 10 & 5.5 & 15 & Out of Agric. Use \\
\hline \multirow{3}{*}{$>5-7.5$} & $\leq 0.5$ & 0.04 & 0.8 & 7.54 & 8.3 & Moderately Potential Risk \\
\hline & $>0.5-\leq 2$ & 0.15 & 3 & 7.65 & 10.5 & High Potential Risk \\
\hline & $>2$ & 0.38 & 7.6 & 7.88 & 15.1 & Out of Agric. Use \\
\hline \multirow[t]{2}{*}{$>7.5-10$} & $\leq 0.5$ & 0.05 & 1 & 10.05 & 11 & High Potential Risk \\
\hline & $>0.5$ & 0.20 & 4 & 10.2 & 14 & Out of Agric. Use \\
\hline
\end{tabular}


Table 8. Classes of Salinity Potential Risks of groundwater

\begin{tabular}{|c|c|c|c|c|c|c|c|c|c|}
\hline $\begin{array}{l}\text { Well } \\
\text { No. }\end{array}$ & $\begin{array}{l}\text { PPRS } \\
\text { H (\%) }\end{array}$ & $\begin{array}{l}\text { APRS } \\
\text { H (\%) }\end{array}$ & $\begin{array}{c}\text { Max. } \\
\text { EC } \\
\left(\mathrm{dSm}^{1}\right. \\
)^{1} \\
\end{array}$ & $\begin{array}{c}\text { Class of } \\
\text { Salinity } \\
\text { Potential Risk }\end{array}$ & $\begin{array}{l}\text { Well } \\
\text { No. }\end{array}$ & $\begin{array}{l}\text { PPRS } \\
\text { H (\%) }\end{array}$ & $\begin{array}{l}\text { APRS } \\
\text { H (\%) }\end{array}$ & $\begin{array}{c}\text { Max. } \\
\text { EC } \\
\left(\mathbf{d S m}^{1}\right)\end{array}$ & $\begin{array}{c}\text { Class of } \\
\text { Salinity } \\
\text { Potential Risk }\end{array}$ \\
\hline \multicolumn{10}{|c|}{ Wells of southern sector of Wadi El-Natrun } \\
\hline 1 & 27.96 & 1.47 & 6.33 & $\begin{array}{c}\text { High Potential } \\
\text { Risk }\end{array}$ & 10 & 11.21 & 0.59 & 1.71 & No Risk \\
\hline 2 & 29.37 & 1.55 & 2.19 & $\begin{array}{c}\text { Moderately } \\
\text { Potential Risk }\end{array}$ & 13 & 20.22 & 1.06 & 5.30 & $\begin{array}{c}\text { High Potential } \\
\text { Risk }\end{array}$ \\
\hline 3 & 10.61 & 0.56 & 1.46 & No Risk & 42 & 25.18 & 0.59 & 1.41 & No Risk \\
\hline 5 & 21.89 & 1.15 & 1.17 & No Risk & 44 & 26.36 & 1.39 & 1.21 & No Risk \\
\hline 6 & 38.08 & 2.0 & 2.03 & No Risk & 45 & 7.07 & 0.37 & 1.42 & No Risk \\
\hline 7 & 20.32 & 1.07 & 3.96 & No Risk & 46 & 17.96 & 0.95 & 1.09 & No Risk \\
\hline \multicolumn{10}{|c|}{ Mean annual salinity increasing of wells of southern sector of Wadi EL-Natrun $=(3.36 \%)$} \\
\hline \multicolumn{10}{|c|}{ Wells of northern sector of Wadi El-Natrun } \\
\hline 50 & 15.70 & 0.83 & 1.18 & No Risk & 62 & 28.09 & 1.48 & 5.17 & $\begin{array}{c}\text { High Potential } \\
\text { Risk }\end{array}$ \\
\hline 51 & 12.82 & 0.67 & 0.98 & No Risk & 63 & 32.06 & 1.69 & 3.84 & $\begin{array}{c}\text { Moderately } \\
\text { Potential Risk }\end{array}$ \\
\hline 53 & -6.48 & -0.34 & 0.8 & No Risk & 67 & 9.28 & 0.49 & 3.0 & $\begin{array}{c}\text { Moderately } \\
\text { Potential Risk }\end{array}$ \\
\hline 54 & 25.23 & 1.33 & 2.28 & No Risk & 68 & 4.93 & 0.26 & 4.38 & $\begin{array}{c}\text { Moderately } \\
\text { Potential Risk }\end{array}$ \\
\hline 55 & 31.58 & 1.60 & 3.66 & $\begin{array}{c}\text { Moderately } \\
\text { Potential Risk } \\
\end{array}$ & 70 & 22.92 & 1.21 & 4.58 & $\begin{array}{c}\text { Moderately } \\
\text { Potential Risk }\end{array}$ \\
\hline 57 & 27.13 & 1.43 & 6.43 & $\begin{array}{c}\text { High Potential } \\
\text { Risk }\end{array}$ & 71 & 10.37 & 0.55 & 2.50 & No Risk \\
\hline 58 & 37.7 & 1.98 & 12.12 & Out of Agr. use & 76 & -1.77 & -0.09 & 1.62 & No Risk \\
\hline 60 & 23.05 & 1.21 & 3.24 & $\begin{array}{c}\text { Moderately } \\
\text { Potential Risk }\end{array}$ & $\begin{array}{l}\text { Mean } \\
\text { sector }\end{array}$ & $\begin{array}{l}\text { nnual sal } \\
\text { f Wadi } \mathrm{F}\end{array}$ & $\begin{array}{l}\text { ity increa } \\
\text { Natrun }=\end{array}$ & $\begin{array}{l}\text { ing of wel } \\
4.48 \%)\end{array}$ & of northern \\
\hline
\end{tabular}

Table 9. Citrus area and yield prediction with time according to water salinity

\begin{tabular}{lcccccc}
\hline \multirow{2}{*}{ Yield (\%) } & \multicolumn{2}{c}{$\mathbf{1 9 6 6}$} & \multicolumn{2}{c}{$\mathbf{2 0 1 5}$} & \multicolumn{2}{c}{$\mathbf{2 0 5 0}$} \\
\cline { 2 - 7 } & ha & $\mathbf{\%}$ & ha & $\mathbf{\%}$ & ha & \% \\
\hline 100 & 5022.5 & 68.80 & 1281.6 & 17.56 & 103.3 & 1.41 \\
\hline $75-99$ & 2235.4 & 30.62 & 1876.7 & 25.71 & 2153.8 & 29.50 \\
\hline $50-74$ & 42.4 & 0.58 & 2481.6 & 33.99 & 1058.1 & 14.49 \\
\hline $1-49$ & 0.0 & 0.0 & 1606.1 & 22.00 & 2785.3 & 38.15 \\
\hline Zero & 0.0 & 0.0 & 54.3 & 0.74 & 1199.9 & 16.44 \\
\hline
\end{tabular}




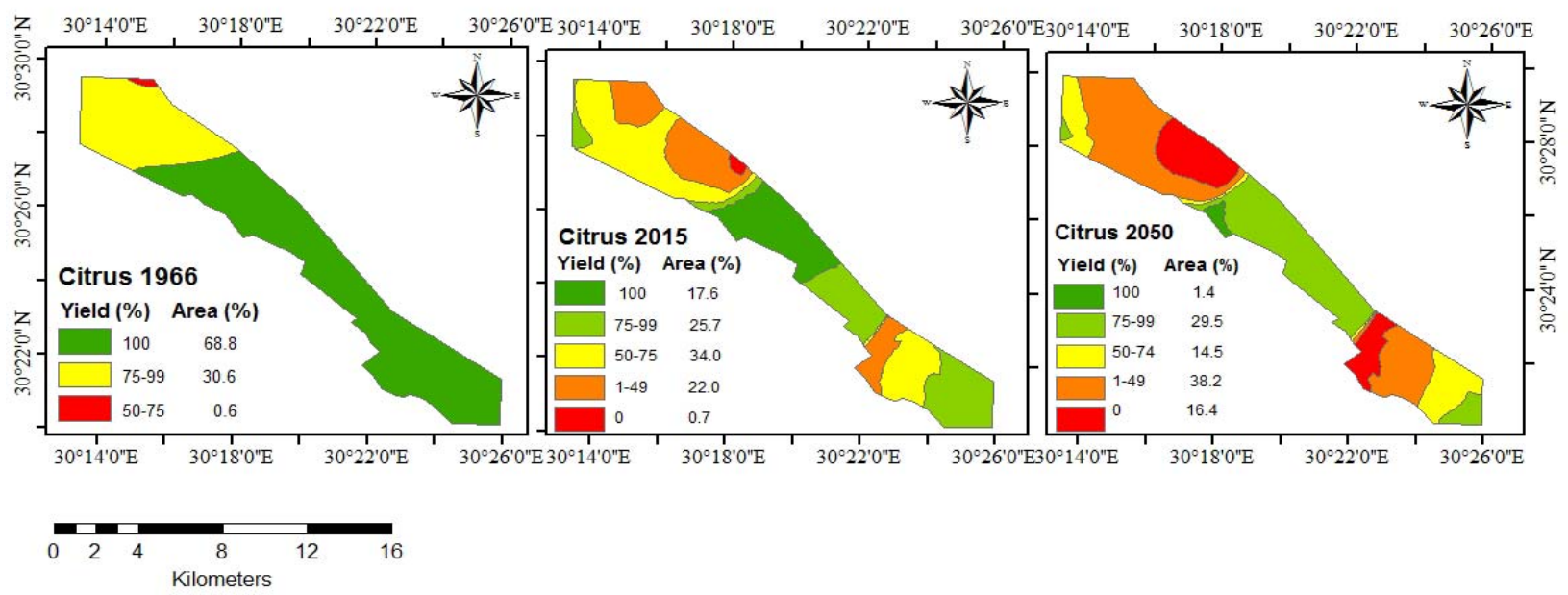

Fig 3. Predicated citrus yield related to groundwater salinity in 1966, 2015 and 2050

Table 10. Tomato area and yield prediction with time according to water salinity

\begin{tabular}{lcccccc}
\hline \multirow{2}{*}{ Yield (\%) } & \multicolumn{2}{c}{$\mathbf{1 9 6 6}$} & \multicolumn{2}{c}{$\mathbf{2 0 1 5}$} & \multicolumn{2}{c}{$\mathbf{2 0 5 0}$} \\
\cline { 2 - 7 } & ha & $\mathbf{\%}$ & ha & $\mathbf{\%}$ & ha & \% \\
\hline 100 & 6565.4 & 89.9 & 2349.6 & 32.2 & 1989.7 & 27.3 \\
\hline $75-99$ & 735.1 & 10.1 & 3709.3 & 50.8 & 1495.3 & 20.5 \\
\hline $50-74$ & 0.0 & 0 & 1184.1 & 16.2 & 2366.9 & 32.4 \\
\hline $1-49$ & 0.0 & 0 & 57.5 & 0.8 & 1390.1 & 19.0 \\
\hline Zero & 0.0 & 0 & 0.0 & 0.0 & 58.4 & 0.8 \\
\hline
\end{tabular}
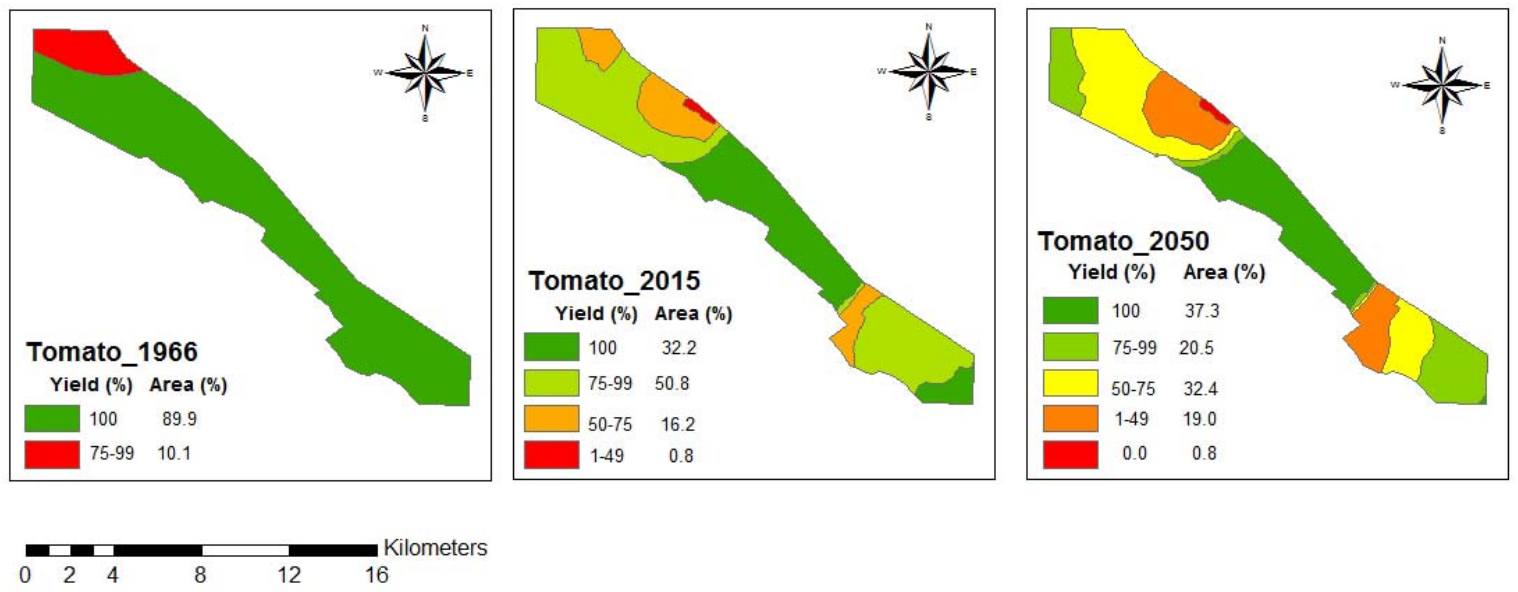

Fig 4.Predicated tomato yield related to groundwater salinity in 1966, 2015 and 2050

\section{CONCLUSION}

According to the historical data of groundwater salinity collected from the area through 1966 to 2014 and forecasting data to 2050 , the results indicated that the groundwater salinity will increase with time and withdrawn of water. The results of crop production showed a reduction of all crops cultivated in the area. Thus, the results in this study is suggested to be a constructed guide for decision makers' attention about the expected groundwater salinity risk in Wadi ElNatrun to supply the area with another low salinity water source to prevent the water salinity risk. In addition, there is a serious need for efficient strategies to ensure long-term sustainability of the region's agricultural production. 


\section{REFERENCES}

Abd El-Hady, A.M.; A.M. Aggag; E.F. Abdelaty and M.H. Bahnassy (2014). Forecasting of Water Crisis and Water Requirements of Wheat Cultivated at the Northern West Coast (Egypt). 17th Annual Energy, Utility and Environment Conference: EUEC 2014, 3-5 Feb, San Diego Phoenix Convention Center, Arizona, USA.

Abd El-Hady, A.M.; A.M. Aggag; E.F. Abdelaty and M.H. Bahnassy (2015). GIS-Forecasted Surface Hydrology for Reducing Risks of Food Production (Northern West Coast, Egypt), accepted $19^{\text {th }}$ Annual Energy, Utility and Environment Conference: EUEC 2016, 3-5 Feb, San Diego Phoenix Convention Center, San Diego, California, USA.

Abdel-Baki, A.A. (1983). Hydrogeological and hydrogeochemical studies on the area west of Rosetta branch and south of El Nasr canal. PhD Thesis, Sci. Fac., Ain Shams Univ.

Ayers, R. S. and D. W. Westcot (1985). Water Quality for Agriculture. Irrigation and Drainage Paper No. 29. FAO, Rome.

Candela, L.; F.J. Elorza; J. Jiménez-Martínez and W. von Igel (2012). Global Change and Agricultural Management Options for Groundwater Sustainability. Computers and Electronics in Agriculture 86 (C): 120-130. doi:10.1016/j.compag.2011.12.012.

Dawoud, A.M. (2004). Design of national groundwater quality monitoring network in Egypt. J. Environ. Monitor. Assess. 96, 99-118. doi: http://dx.doi.org/10.1016/j.jafrearsci.2014.03.006 (Last accessed June, 2015).

Egyptian Meteorological Authority, Cairo, Egypt (2006) International Journal of Meteorology: Vol 31, No. 308.

El-Arabi, N. (2012). Environmental Management of Groundwater in Egypt via Artificial Recharge Extending the Practice to Soil Aquifer Treatment (SAT). inter. J. environ. Sustain. 1(3): 66-82.

El-Maghraby, M.M. (1990). Geographical and hydorological studies of Sadat City, Egypt. M.Sc. Thesis, Fac. Sci., Alex. Univ.

ESRI (2010). ArcMap, 10.0 user manual. Environmental Systems Research Institute. U.S. Copyright 2010 ESRI Inc.

Fathony, R. Z. A.; S. H. Wibowo and L. Amelia (2009). Zaitun time series. Free time series analysis and forecasting software. Copyright@ zaitunsoftware.com.

Fattah, M.K. (2011). Hydrogeochemical Evaluation of the Quaternary Aquifer in El Sadat City, Egypt. Arabian J. Sci. Engin. 37(1): 121-145. doi:10.1007/s13369-0110146-5.

Government of Western Australia, Department of Agriculture (2015). Water salinity and plant irrigation. https://www.agric.wa.gov.au/fruit/water-salinity-andplant-irrigation.
Green, T.R.; M. Taniguchi; H. Kooi; J.J. Gurdak; D.M. Allen; K.M. Hiscock; H. Treidel and A. Aureli. (2011). Beneath the Surface of Global Change: Impacts of Climate Change on Groundwater. J. Hydrol. 405(3-4): 532-560.

Ibrahim, S. (2005). Groundwater Resources Management in Wadi El-Farigh Area and Its Vicinities for Sustainable Agricultural Development. Cairo, Egypt: Faculty of Engineering, Ain Shams University.

Kim, J.H.; J. Lee; T.J. Cheong; D.C. Kim; J.S. Ryu and H.W. Chang (2005). Use of time series analysis for the identification of tidal effect on groundwater in the coastal area of Kimje, Korea. J. Hydrol. 300:188-98.

King, C. and B.B. Salem (2012). A Socio-Ecological Investigation of Options to Manage Groundwater Degradation in the Western Desert, Egypt. Ambio 41 (5): 490-503. doi:10.1007/s13280-012-0255-8. (Last accessed Aug. 2015).

Lee, J.Y. and K.K. Lee (2000) Use of hydrologic time series data for identification of recharge mechanism in a fractured bedrock aquifer system. J. Hydrol. 229:190-201.

Masoud, A.A. (2014) .Groundwater quality assessment of the shallow aquifers west of the Nile delta (Egypt) using multivariate statistical and geostatistical techniques. African Earth Sciences.

Masoud, A.A. and M.G. Atwia (2011). Spatio-temporal Characterization of the Pliocene Aquifer Conditions in Wadi El-Natrun Area, Egypt. J. Environ. Earth Sciences. 62 (7), 1361-1374

Sabbah, M.A. and A.A. Metwally (1997). Desert Irrigation Efficiency Final Report to International Development Research Center of Canada (IDRC). 93-8606. The American University in Cairo.

Sharaky, A.M.; S.A. Atta,; A.S. El Hassanein and K.M.A. Khallaf (2007). Hydrogeochemistry of groundwater in the western Nile Delta aruifers, Egypt. $2^{\text {nd }}$ Intern. Conf. on the Geology of Tethys, 19-21 March, 2007 Cairo University. Pp.23.

Switzman, H. R. (2013). Groundwater, environmental change and conservation in north Egypt. MSc thesis. Mcmaster University.

Terink, W.; W. W. Immerzeel and P. Droogers (2013). Climate Change Projections of Precipitation and Reference Evapotranspiration for the Middle East and Northern Africa until 2050. International Journal of Climatology: 1-18. doi:10.1002/joc.3650.

Tularam, G.A. and H.P. Keeler (2006). The study of coastal groundwater depth and salinity variation using time-series analysis. Environ. Impact Assess. Review. 26: 633-642

Wikipedia (2015). Time series. http://en.wikipedia.org/wiki/Time series. (Last accessed Jan. 2016)

Youssef, T.; M.I. GAD and M.M. Ali (2012). Assessment of Groundwater Resources Management in Wadi El-Farigh Area Using MODFLOW. IOSR Journal of Engineering. 2(10): 69-78. 


\section{الملخص الهرب}

التنبؤبتغيرات ملوحة الميل الجوفية وإنتاج بهض المحاصلل بولملة التكالل بن تحللل السلالل الزمنية

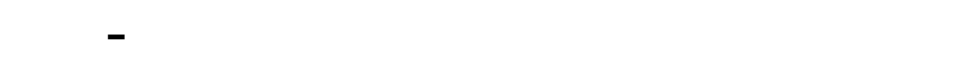

لحمدمحمد لحمد عجاج

وادى الطرون. التوصيل الكهربى المتنبأ به والمقيلس المبتكر لستخما للتنبؤ بالمخطار المحتملة واضضرار الأملاح

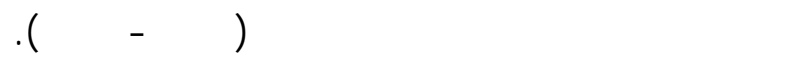

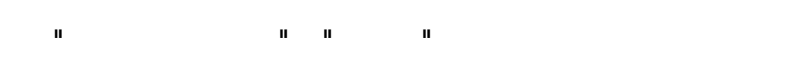

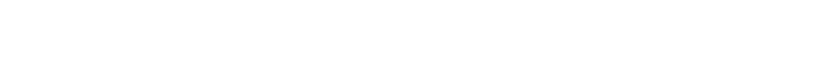

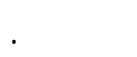

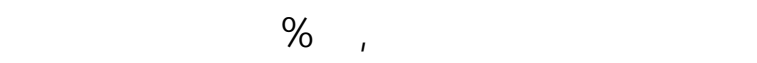

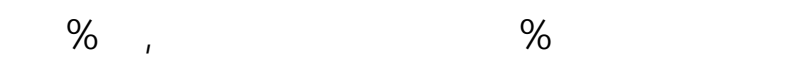
المسلحة تنتج من V0 اللى 9 \% من من النتاج الموالح. بينما

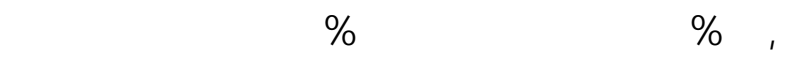

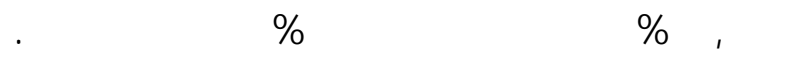

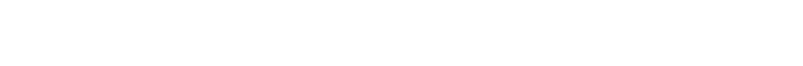

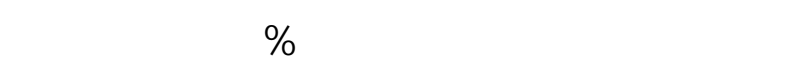

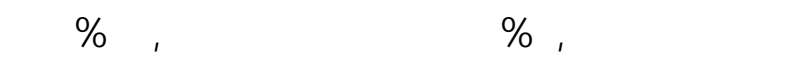

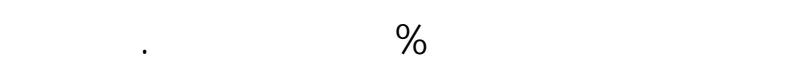
الوقت عع,7 ا \% من المسلحةستصنح غير صالحة لإنتاج

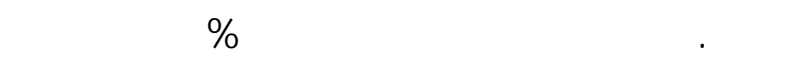

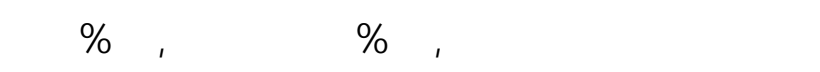
المسلحة ستنتج ألق من . \% من النتاج الطمطلم. وعليه

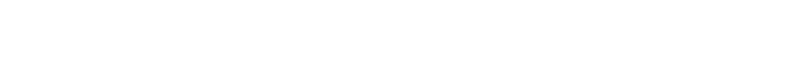
التركيز الكلى للأملاح في الميل الجوفية المتوقع في مطظقة

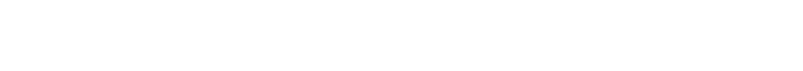
الأملاح لمنع خطر الأملاح في ميل الرى المداد
تخضع مطقة وادى الطرون مؤخراً للامتداد العمرالف

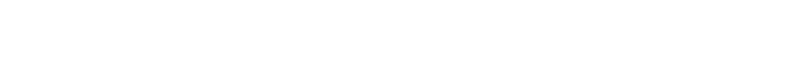

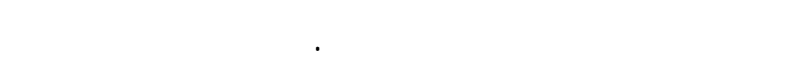

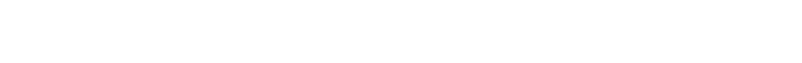
الميل وبالتالي انخفاض في إنتلجية المحاصيل. لذاك الهنف

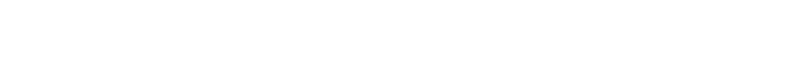
لمستمرارية الإنتاج الزراعى على المدى الطويل.

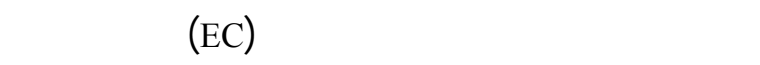

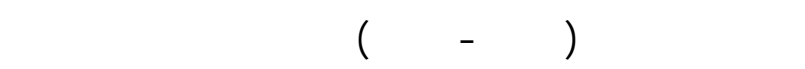
بمظقة وادى الطرون لطبيق التحليل الإحصائي للسلملال

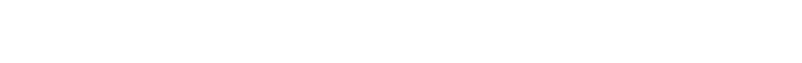

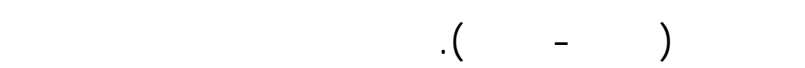

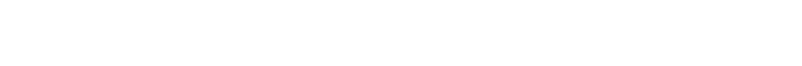
ولأكتشف التغيرات اللسنوية والمرحلية الملوحة الميله الجوفية وقفير المخطار المحتملة من مشلكل الأملاح

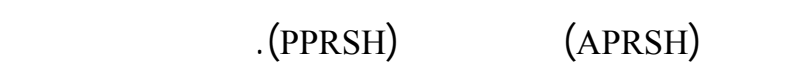

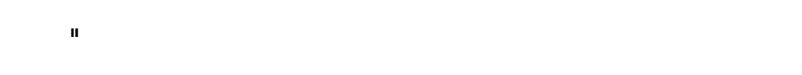

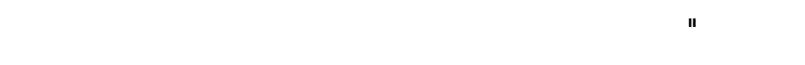

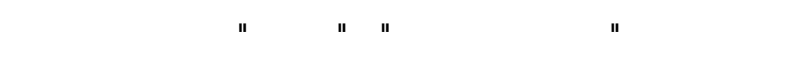
الجنوبى من وادى الطرون. التغيرات المنوية في التركيز

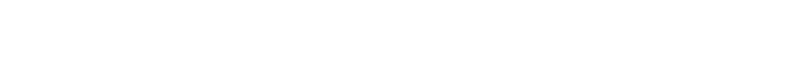

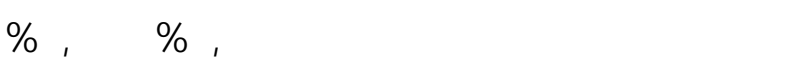

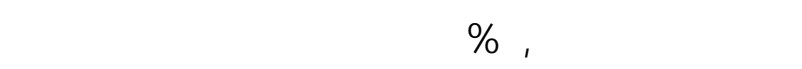

